\section{Conservation in vogue}

FRENCH nuclear power is increasingly abundant, supplies of natural gas from Siberia and Algeria will soon outstrip demand and the French government has set up a study group to invent new ways of using electricity. So why does France need the Agence Française pour la Maitrise de l'Energie (AFME), which last year spent some FF 2,500 million ( $£ 210$ million) on supporting energy conservation and renewable energies in community housing, industry and research? Because it pays, a team of financial inspectors has concluded.

The inspectors were provided by finance minister, Pierre Bérégovoy, who is now tearing his hair out over the 1986 (election year) budget, due to go before parliament in November but to the Council of Ministers much sooner. Bérégovoy, who, like most finance ministers, is looking for savings, wondered if an increase in energy taxes could be arrange not only to increase revenue but also to save energy.

According to AFME sources who have had a chance to look over the inspectors' work, their conclusion - which is not due to be published - is that the "interventionism" represented by AFME is the best way of achieving energy savings. Moreover, AFME itself is the best way of going about the intervention.

AFME director-general M. Bernard Laponche says there has always been "tension" over AFME and its policy of investment aids. The tension arises between the "technical ministries" of industry, energy and research, backed by President Mitterrand himself, and the financial sources. Matters may have been made worse by last year's figures which show French primary energy consumption rising by 2 per cent despite AFME's investments, some 80 per cent of which go towards saving or substituting for oil.

But says the ex-trades unionist president of AFME, M. Michel Rolant, his agency's actions saved 2.2 million tons of oil equivalent (t.o.e.) in 1984 in a total of 191.6 million t.o.e., so things would have been worse without AFME. Moreover, the general export trade improved in France last year because of the cheap franc, so a little AFME juggling shows that the French energy bill went down last year - when measured in terms of months of general exports. In 1984, France worked just two and a half months to pay its energy import bill, the lowest since 1980 .

In reality, it is still the cost of oil imports that makes AFME's work politically attractive. In its medium-term programme, AFME aimed to produce energy savings over the decade 1981-90 of 40 million t.o.e., more than a fifth of oil imports, of which some 20 million t.o.e. were to come from improving home insulation and 10 million from industry; renewables, which contributed 3.4 million t.o.e. in 1981, were planned to bring in 10-14 million t.o.e. in 1990 , mostly from biomass.

There is still a long way to go to reach those targets (set nearly three years ago) but AFME staff are encouraged by the fact that in 1984, for the first time, energy savings profited the balance of payments by more than AFME aid itself - FF 3,000 million against FF 2,500 million. Nevertheless, AFME aid is rarely 100 per cent, so that actual energy-saving or energy-substituting investments in France last year amounted to some FF 11,000 million. This sum may take a considerable time to pay off.

Robert Walgate

\section{Soviet Union}

\section{Phobos mission}

THE Soviet Union is planning the first-ever mission to Phobos, the larger and inner moon of Mars, in 1988. The two-probe mission will include a close fly-by of the satellite, at an altitude of $50 \mathrm{~m}$, during which a laser gun will be fired to stir up surface dust which will then be captured and analysed.

This will be the first Soviet mission to Mars since 1973. Eighteen months ago, Aviation Week and Space Technology suggested that the Soviet Union was planning a mission to Phobos, with an approach to within "a few thousand feet" for 1986.

The actual plans for the mission, at present code-named "Mission-F", seem considerably more sophisticated than the Aviation Week speculations, which suggested that the Soviets had abandoned Mars flights because of 14 failures or partial failures out 'of 15 launches or attempted launches between 1960 and 1973. The Soviets, they said, had realized that they could not compete with the plans for the US orbiter/lander mission. In the opinion of Aviation Week, the projected Phobos flight was simply a "poor man's asteroid mission".

Perhaps in answer to such smears, the Soviet space planners are trying to make the Phobos mission as international as possible. Sweden's Kiruna Geophysical Institute has been invited to supply an instrument for measuring the energy and mass of solar wind particles around Mars and Phobos. Poland will supply a device to study plasma-waves, similar to those supplied to the Venus-Halley probes now in flight. Bulgarian and West German scientists are developing a special laser mass spectrometer in conjunction with their Soviet colleagues; the East Germans will supply optical systems for filming and mapmaking and there are plans for a joint Soviet-French device for studying the chemical composition of the martian atmosphere.
Chromosome libraries \section{Ploughshares from swords?}

\section{Los Alamos, New Mexico}

$\mathrm{AN}$ ambitious project to create the first human chromosome-specific gene libraries is expected to have covered the entire genome by the end of the year. The libraries, which are being constructed at Los Alamos and Lawrence Livermore National Laboratories, are already attracting strong commercial and scientific interest. Once the project is complete, the rate of human gene mapping will increase by a factor of ten, according to the project team; batteries of probes for chromosome-specific diseases and chromosome-specific stains are among the other benefits expected.

Twelve commercial companies are among the 500 organizations that have already received chromosome libraries from the National Laboratory Gene Library Project. Investigators who receive libraries (free of charge) are asked to inform the project of whatever characterizations they make. The libraries so far available are made using two different restriction enzymes - HindIII at Livermore and EcoRrI at Los Alamos. The cloned DNA fragments are up to 9 kilobases long. Now it is planned to produce 17-kilobase fragments, which are more likely to contain entire functioning genes and will be of greater use in basic molecular biology. Lawrence Livermore and Los Alamos National Laboratories are primarily weapons laboratories and not the most obvious places to find a cloning project. According to Larry Deaven, principal project investigator at Los Alamos, the laboratories were chosen because of their expertise in chromosome sorting, which arose from studies of the effects of radiation on animal cells.

The chromosomes for the libraries are extracted either from human fibroblast cell lines or from hybrid human/hamster cells. After treatment with two fluorescent dyes, different chromosomes are separated automatically under laser light. Chromosomes that are not easily distinguished with two dyes are subjected to a third stain: according to Deaven, the chromosomes that are easy to separate have now all been cloned and "we're left with the hard ones". The efficiency of cloning has improved dramatically since the project started in 1983: whereas several million chromosomes were then needed to start a library, the figure is now down to 100,000 .

The library project, at present supported by the Department of Energy with a budget of $\$ 400,000$ this year, will not always remain at Los Alamos and Livermore. As soon as both phases have been successfully completed, stocks will be handed over to the National Institutes of Health, which will also maintain information on the libraries. 